Received 15.05.2017

Reviewed 13.06.2017

Accepted 17.07.2017

A - study design

B - data collection

C - statistical analysis

D - data interpretation

$\mathbf{E}$ - manuscript preparation

F - literature search

\title{
Investigations of the mechanism of the fouling in microgranular adsorptive filtration
}

\author{
Beata MALCZEWSKA ${ }^{\mathrm{ABCDEF} \otimes}$
}

Wrocław University of Life Sciences, Faculty of Environmental Engineering and Geodesy, Institute of Environmental Engineering, pl. Grunwaldzki 24, 50-363 Wrocław, Poland; e-mail: beata.malczewska@upwr.edu.pl

For citation: Malczewska B. 2017. Investigations of the mechanism of the fouling in microgranular adsorptive filtration. Journal of Water and Land Development. No. 35 p. 137-140. DOI: 10.1515/jwld-2017-0077.

\begin{abstract}
The application of microgranular adsorptive filtration ( $\mu \mathrm{GAF}$ ) has been successfully used in conjunction with membrane filtration. It proves to be efficient not only in removal of natural organic matter (NOM) but also it significantly reduces the extent of fouling. There are a few mathematical models evaluated to understand the underlying mechanism of fouling. This paper describes a method of predicting filtration capacities using constant flow datasets collected when $\mu \mathrm{GAF}$ was applied. The results suggest that the behaviour of fouling in microgranular adsorptive filtration system varies between different filtration operations and natural water quality. In analysed case the mechanism of pores blocking can be described by the complete blocking mechanism.
\end{abstract}

Key words: constant flow fouling models, membrane filtration, membrane fouling, pore blocking

\section{INTRODUCTION}

The filtration process is widely used, particularly in water supply but also in industrial and municipal wastewater treatment plants. The filtration through the membrane is susceptible to fouling, resulting in significant reduction of the filtration efficiency and increase the costs of the process. Fouling is consider to be connected with clogging of the pores, and the formation of the cake layer, as well as the concentration polarization on the membrane surface.

The modelling of filtration process is difficult due to influence of various factors [MARCINKOWSKI et al. 2016; MioduszewSKi et al. 2014; SCHALLER et al. 2006]. For example, the mechanism in ultrafiltration (UF) is not clearly explained mainly because of the diversity of its application in different arrangements. Moreover, the filtration models are usually divided onto two main groups: dead-end mode and cross-flow mode. Usually to describe the mechanism of permeation two flow models are commonly used: pore-flow model (permeates are transported by pressure-driven convective flow) and solution-diffusion model. The pore-flow model is the most common and it describes the flux across the membrane based on Darcy's law:

$$
J=\frac{\Delta P}{\eta\left(R_{M}+R_{c}\right)}
$$

where: $\Delta P=$ transmembrane pressure, $\mathrm{Pa} ; \eta=$ the solution viscosity, Pa-s; $R_{M}=$ the hydrodynamic resistance of clean membrane, $1 \cdot \mathrm{m}^{-1} ; R_{c}=$ the resistance of the concentration polarization layer, $1 \cdot \mathrm{m}^{-1}$.

The difference between the solution-diffusion and pore-flow mechanisms lies in the relative size and permanence of the pore [BAKE 2004]. Mathematical mechanism of membrane fouling based on blocking filtration law was described by the Hermia's models [ARYANTI et al. 2016; HERMIA 1982; KONIECZNY, RAFA 2000; RAJCA 2011]. The equations come with their limits, though. Both dead-end and constant pressure filtration are required to use them. Moreover, Hermia's models are based on the assumption that single fouling mechanism dominates in given system [HERMIA 1982; BENJAMIN, LAWLER 2013]. In general, four fouling mechanisms can be observed: com- 
plete pore blocking, internal pore blocking, partial pore blocking, and cake filtration. In 1993, HLAVACEK and BOUCHET [1993] modified Hermia's for porous membranes equations for constant flowrate condition.

When particles are larger than the pore size, they completely block pores and in such case the complete blocking model can be applied. The intermediate blocking model is used when particles smaller than the pore size enter the pores and get either adsorbed or deposited onto the pore walls. And when particles get accumulated inside the membrane on the pore walls and the resulting constrictions of pores reduce the membrane's permeability the standard blocking model can be used [FIELD 2010; SAMPATH et al. 2014]. These mechanisms have been used individually as well as in combination to explain experimental various observations [HALE, DANIELS 1961; HO, ZYDNEY 2000; SAMPATH et al. 2014].

Fouling is affecting the hydraulics by decreasing the flux, when fixed TMP (Transmembrane Pressure) is used, or increasing TMP for a fixed flux. At the same time, it contributes to the change of the effective pore size distribution.

Many studies were devoted to mitigating membrane fouling and enhancing membrane process performance. Among others the pretreatment of water is most common technique. There are different approaches for pretreatment like pre-filtration through granular media or coarser membranes, or applying coagulation/adsorption and pre-oxidation [LIU 2015]. One of the newest approaches is raw water pretreatment by micron-sized heated aluminium oxide particles (HAOPs) prior to membrane filtration, so called micro-granular adsorptive filtration $(\mu \mathrm{GAF})$. The process integrates granular media filtration and packed bed adsorption [CAI et al. 2008; KIM et al. 2007; 2008; 2010; LIU 2015; MALCZEWSKA 2016; MALCZEWSKA, BENJAMIN 2016; MALCZEWSKA et al. 2015]. The aim of this paper was to estimate the fouling parameters using the experimental data for microgranular adsorptive filtration.

\section{MATERIALS AND METHODS}

Lake Union, located in Seattle, WA, was used as the source of natural water. The detailed description of experimental setup is presented in the publication MALCZEWSKA and BENJAMIN [2016]. Briefly, the stainless steel mesh (\#316) had a $200 \times 1400$ twilled Dutch weave pattern with nominal $10-\mu \mathrm{m}$ openings (Howard Wire Cloth Corp., Hayward, CA) was used as the adsorbent ( $\mu \mathrm{GAF}$ ) support media. The tubes of mesh were set vertically and operated with dead-end and inside-out filtration mode. After HAOPs were deposited on the tube inside wall, the water filtration started with the flux set up as $150 \mathrm{dm}^{3} \cdot \mathrm{m}^{-2} \cdot \mathrm{h}^{-1}$ (commonly referred as LMH) and then $250 \mathrm{dm}^{3} \cdot \mathrm{m}^{-2} \cdot \mathrm{h}^{-1}$. Then, the water samples were analysed on a UV-Vis spectrophotometer at a wavelength of $254 \mathrm{~nm}$. UV254 $\mathrm{nm}$ was measured with a dual-beam Lambda-18 spec- trophotometer with a $1 \mathrm{~cm}$ quartz cell (Lambda-18, Perkin-Elmer, USA).

In this study, filtration experiments were operated under two different constant flowrates and dead-end filtration, therefore Hlavacek and Bouchet's models were chosen for fitting the experimental data.

\section{RESULTS AND DISCUSSION}

Figure 1 shows the TMP that is required to maintain the constant flux of $150 \mathrm{dm}^{3} \cdot \mathrm{m}^{-2} \cdot \mathrm{h}^{-1}$ and 250 $\mathrm{dm}^{3} \cdot \mathrm{m}^{-2} \cdot \mathrm{h}^{-1}$, as a function of filtration time. HAOPs pretreatment removed substantial amounts of NOM from tested samples and significantly mitigated fouling by all them regardless of increasing flux.

Presented results confirm existing reports that passage of feed through a thin layer of pre-coated HAOPs removes NOM and membrane foulants and substantially removes the majority of the UV254 from the raw water [CAI et al. 2008; KIM et al. 2007; 2008; 2010; LIU 2016; MALCZEWSKA 2016; MALCZEWSKA, BENJAMIN 2016; MALCZEWSKA et al. 2015].

The blocking filtration law models for constant flowrate condition is expressed in the term of $\triangle P$ (an effective or transmembrane pressure $(\mathrm{Pa})$ ) and $V s p$ (defined as the cumulative permeate volume per unit of membrane area) as shown in Figure 2.

The Table 1 provides membrane fouling models for constant flowrate condition and estimated values of parameters for both analysed flux. The estimation of mathematical models of fouling mechanisms using filtration blocking laws was investigated to predict the main fouling mechanisms when natural water passed through a thin layer of HAOPs (Tab. 1). The best fit model for the measurement data is the complete blocking law, with linear regression coefficients $R^{2}$ of $0.94-0.96$, the standard blocking gave the $R^{2}$ between 0.93 and 0.94 ; and in case of the intermediate blocking law the $R^{2}$ was between 0.92 and 0.93 . The complete blocking of the pores of $\mu \mathrm{GAF}$ is the most adequate for fouling description. The particles/solutes accumulate on the HAOPs layer and they do not overlap to other solute that has been previously deposited on the surface.

ARYANTI et al. [2016] studied the principles and fouling analysis of konjac glucomannan discovered that the fouling mechanism was controlled by complete blocking and cake/gel formation, respectively. This results are supported by GIJIU et al. [2012] they reported when combined complete pore blockagecaking filtration model is the most suitable model for their experimental data. On the other hand, Su et al. [2015] when studied the effect of hydrophobic and hydrophilic fractions on membrane fouling. They discovered that hydrophobic fractions exhibited a cake layer as the major fouling mechanisms, while the intermediate blocking was caused by the hydrophilic fraction. Others argued that standard blocking of the pores of ultrafiltration (UF) and microfiltration (MF) membranes is usually the most adequate [LE-CLECH 

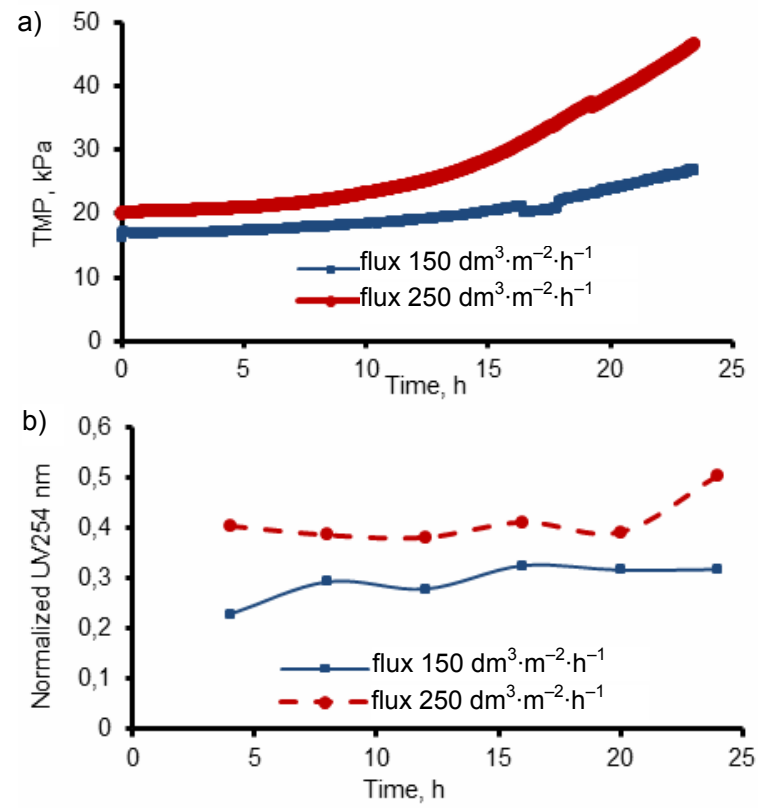

Fig. 1. Experimental data generated for constant flow rate during the operation period: a) transmembrane pressure (TMP) profiles during membrane filtration, $b$ ) normalized

UV $254 \mathrm{~nm}$ (permeate/feed) whereas samples were collected at pre-selected intervals for analysis of UV absorbance; source: own study
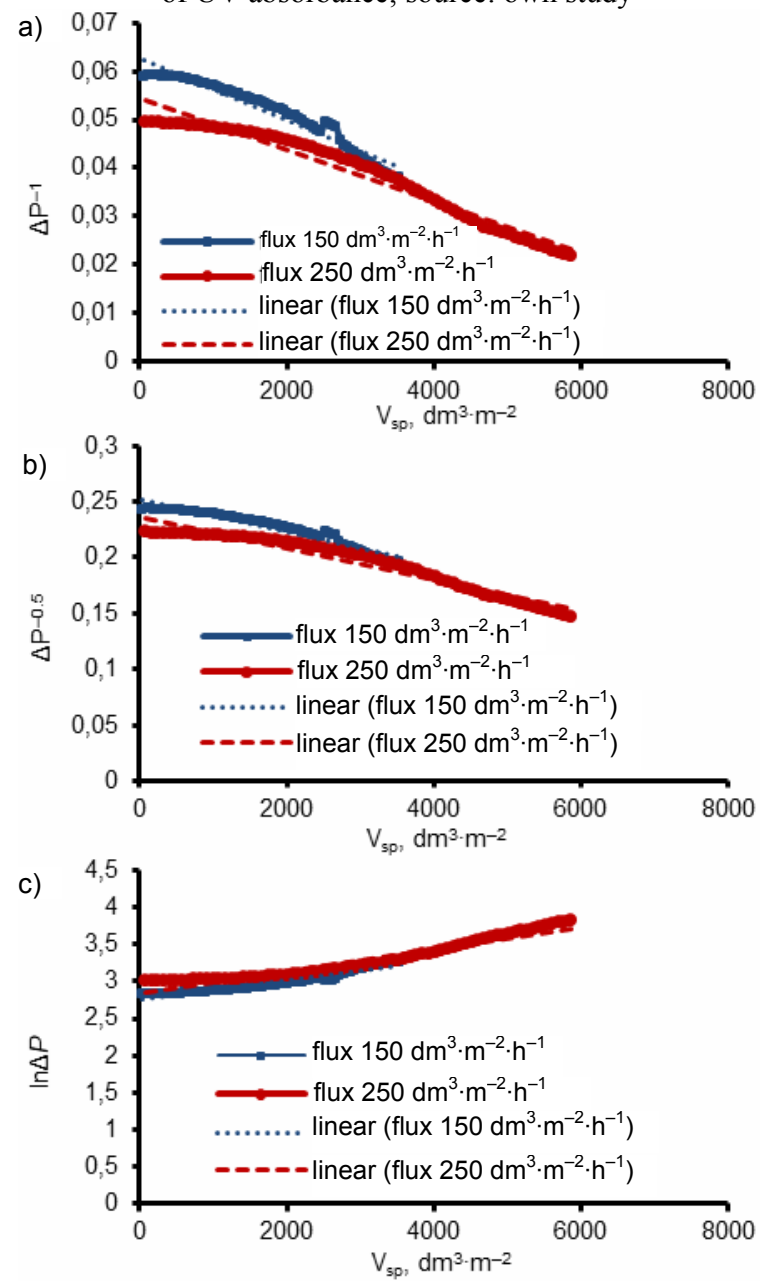

Fig. 2. Blocking filtration law analysis of $\mu \mathrm{GAF}$ :

a) complete blocking, b) standard blocking, c) intermediate blocking law; source: own study
Table 1. The fouling models for constant flowrate and estimated values of parameters for both analysed flux

\begin{tabular}{|c|c|c|c|}
\hline $\begin{array}{l}\text { Pa- } \\
\text { rame- } \\
\text { ter }\end{array}$ & $\begin{array}{l}\text { Complete blocking } \\
\qquad \frac{1}{\Delta P}=a+b V\end{array}$ & $\begin{array}{l}\text { Standard blocking } \\
\frac{1}{\sqrt{\Delta P}}=a^{\prime}+b^{\prime} V\end{array}$ & $\begin{array}{c}\text { Intermediate } \\
\text { blocking } \\
\ln \Delta P=a^{\prime \prime}+b^{\prime \prime} V\end{array}$ \\
\hline \multicolumn{4}{|c|}{ Flux $150 \mathrm{dm}^{3} \cdot \mathrm{m}^{-2} \cdot \mathrm{h}^{-1}$} \\
\hline$a$ & 0.0627 & 0.2517 & 2.7475 \\
\hline$b$ & -0.000006 & -0.00001 & 0.0001 \\
\hline$R^{2}$ & 0.944 & 0.9314 & 0.9173 \\
\hline \multicolumn{4}{|c|}{ Flux $250 \mathrm{dm}^{3} \cdot \mathrm{m}^{-2} \cdot \mathrm{h}^{-1}$} \\
\hline$a$ & $-5 \mathrm{E}-06$ & 0.2364 & 2.846 \\
\hline$b$ & 0.0544 & -0.00001 & 0.0001 \\
\hline$R^{2}$ & 0.959 & 0.9444 & 0.9257 \\
\hline
\end{tabular}

Source: own study.

et al. 2006; POLYAKOV et al. 1999]. LIU [2015] evaluated fouling of the $\mu \mathrm{GAF}$ and modeled it by Hermia's intermediate fouling model when cartridge system was used. On the other hand, this study conducted on the tubular system showed that best model describes the phenomenon of fouling is the complete blocking law.

\section{CONCLUSION}

Fouling is a major problem and the most challenging obstacle in the application of the membrane technology. There are a few mathematical models evaluated to understand the underlying mechanism of fouling.

In this case, the blocking filtration law models for constant flow rate based on Hlavacek and Bouchet's model were used. The results suggest that the behaviour of fouling in micro-granular adsorptive filtration system varies between different filtration operations and natural water quality.

This suggests that the mathematical description of fouling is more complex than a model assuming one of its components constant.

Acknowledgement

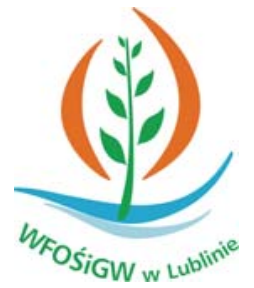

Dofinansowano ze środków Wojewódzkiego Funduszu Ochrony Środowiska i Gospodarki Wodnej w Lublinie Cofinanced by Voivodeship Fund for Environmental Protection and Water Management in Lublin

\section{REFERENCE}

ARYANTi N., Wardhani D.H., SUPANDi S. 2016. Flux profiles and mathematical modeling of fouling mechanism for ultrafiltration of konjac glucomannan. Scientific Study and Research, Chemistry and Chemical Engineering, Biotechnology, Food Industry. Vol. 17. Iss. 2 p. 125-137.

BAKE R.W. 2004. Membrane technology and application. Chichester, West Sussex PO19 8SQ, England. Wiley. ISBN 9780470854457 pp. 538.

BENJAMIN M.M., LAWLER D.F. 2013. Water quality engineering: Physical / chemical treatment processes. John Wiley and Sons Ltd. ISBN 978-1-118-16965-0 pp. 904. 
CAI Z., Kim J., BENJAMIN M.M. 2008. NOM removal by adsorption and membrane filtration using heated aluminum oxide particles. Environmental. Science and Technology. Vol. 42. Iss. 2 p. 619-623.

FIELD R. 2010. Fundamentals of fouling. In: Membranes for water treatment. Vol. 4. Ed. K.-V. Peinemann, S.P. Nunes. WILEY-VCH Verlag GmbH \& Co. KGaA, Weinheim p. 1-23.

Gijiu C.L., Dima R., RAluca, IsOPescu R.D. 2012. Membrane fouling in dead-end microfiltration of yeast suspensions [online]. Revista De Chimie. Vol. 63. No. 1 [Access 12.05.2017]. Available at: http://www. revistadechimie.ro/pdf/GIJIU\%20C\%201\%2012.pdf

Hale M.B., Daniels W.F. 1961. A preliminary study of depth filtration at a constant rate. Biotechnology and Bioengineering. Vol. 3. Iss. 2 p. 139-150.

HeRmia J. 1982. Constant pressure blocking filtration laws - Application to power-law non-Newtonian fluids. Institution of Chemical Engineers. Transactions. Vol. 60. No. 3 p. $183-187$

HlavaceK M., Bouchet F. 1993. Constant flowrate blocking laws and an example of their application to deadend microfiltration of protein solutions. Journal of Membrane Science. Vol. 82. Iss. 3 p. 285-295.

Ho C.C., ZydNeY A.L. 2000. A combined pore blockage and cake filtration model for protein fouling during microfiltration. Journal of Colloid and Interface Science. Vol. 232. Iss. 2 p. 389-399.

KIM J., CAi Z., BENJAMIN M.M. 2008. Effects of adsorbents on membrane fouling by natural organic matter. Journal of Membrane Science. Vol. 310. Iss. 1-2 p. 356-364.

KIM J., CAI Z., BENJAMIN M.M. 2010. NOM fouling mechanisms in a hybrid adsorption/ membrane system. Journal of Membrane Science. Vol. 349. Iss. 1-2 p. 35-43.

Kim J., ShI W., Yuan Y., Benjamin M.M. 2007. A serial filtration investigation of membrane fouling by natural organic matter. Journal of Membrane Science. Vol. 294. Iss. 1-2 p. 115-126. DOI 10.1016/j.memsci.2007.02. 020.

KONIECZNY K., RAFA J. 2000. Modeling of the membrane filtration process of natural waters. Polish Journal of Environmental Studies. Vol. 9. No. 1 p. 57-63.

LE-CleCh P., ChEN V., FANE T.A. 2006. The application of constant temperature anemometry to membrane processes. Journal of Membrane Science. Vol. 284. Iss. 1-2 p. 416-423.
LIU J.C.W. 2015. Effects of operational parameters on microgranular adsorptive filtration $(\mu \mathrm{GAF})$. PhD Thesis. University of Washington pp. 115.

MALCZEWSKA B. 2016. Evaluation of effectiveness of natural organic compounds removal from water in hybrid processes. Journal of Land Water Development. No. 30 p. 81-85. DOI 10.1515/jwld-2016-0024.

MALCZEWSKA B., BeNJAMIN M.M. 2016. Efficacy of hybrid adsorption/membrane pretreatment for low. Water Research. Vol. 99 p. 263-271.

MalczewsKa B., LiU J., Benjamin M.M. 2015. Virtual elimination of MF and UF fouling by adsorptive precoat filtration. Journal of Membrane Science. Vol. 479 p. $159-164$.

MarcinKowski P., Piniewski M., KARdel I., SRINIVASAN R., OKRUSZKO T. 2016. Challenges in modelling of water quantity and quality in two contrasting meso-scale catchments in Poland. Journal of Water and Land Development. No. 31 p. 97-111. DOI 10.1515/jwld-2016-0040.

Mioduszewski W., Querner E.R., KowalewsKi Z. 2014. The analysis of the impact of small retention on water resources in the catchment. Journal of Water and Land Development. No. 23 p. 41-51.

Polyakov Yu.S., Maksimov E.D. Polyakov V.S. 1999. On the design of microfilters. Theoretical Foundations of Chemical Engineering. Vol. 339. Iss. 1 p. 64-71.

RAJCA M. 2011. NOM fouling mechanism during ultrafiltration. Architecture Civil Engineering Environment. Vol. 1 p. 113-119.

SAmpath M. ShuKLa A., RATHORE A.S. 2014. Modelling of filtration processes - microfiltration and depth filtration for harvest of a therapeutic protein expressed in Pichia pastoris at constant pressure. Bioengineering. Vol. 1. p. 260-277.

Schaller J., Drews A., Kraume M. 2006. Analyses of filtration mechanisms in membrane bioreactors and test cells by mathematical modelling. 16th International Conference Process Engineering and Chemical Plant Design. Berlin 9-13.10.2006. Berlin. Technische Universität p. 33-42.

Su W., Chen C., Zhu Y., YAnd W., Dai H. 2015. Fouling characteristics of dissolved organic matter in papermaking process water on polyethersulfone Ultrafiltation membranes. BioResources. Vol. 10. No. 3 p. 59065919.

\section{Beata MALCZEWSKA}

\section{Badanie mechanizmu zatykania porów membrany (foulingu) w przypadku zastosowania filtracji $\mu$ GAF}

\section{STRESZCZENIE}

Mikro-ziarnowa adsorpcyjna filtracja ( $\mu \mathrm{GAF})$ jest $\mathrm{z}$ powodzeniem stosowana w połączeniu z filtracją membranowa. Metoda ta jest skuteczna nie tylko w usuwaniu naturalnych substancji organicznych (NOM), ale również znacznie zmniejsza stopień zatkania się podczas filtracji porów membrany (proces foulingu). Aby zrozumieć zjawisko foulingu, opracowano kilka modeli matematycznych. W niniejszej pracy opisano mechanizm blokowania porów podczas $\mu$ GAF filtracji. Uzyskane wyniki dają podstawy do przypuszczeń, że w zależności od zastosowanego systemu oraz właściwości chemicznych i fizycznych filtrowanej wody różne modele matematyczne mogą mieć zastosowanie. W analizowanym przypadku mechanizm blokowania porów najlepiej opisuje model całkowitego zatykania porów.

Słowa kluczowe: filtracja membranowa, fouling, model zatykania porów ze stałym przepływem, zatykanie porów 